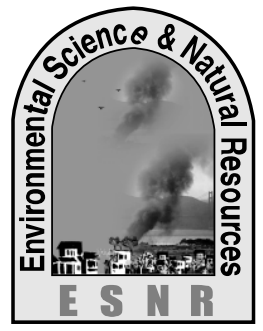

\title{
Assessment of Structural and Functional Status in High-rise Building in Tangail Pourashava
}

\section{J. Uddin*, A. Adnan, N. Sultana, M. G. Muktadir and S. M. F. Sazzad}

Department of Environmental Science and Resource Management, Mawlana Bhashani Science and Technology University, Tangail

*Corresponding author: muhammadjasimuddin@yahoo.com

\begin{abstract}
Today, most of the cities in the world encounter the phenomenon of high rise building. The growth of high rise building in Tangail pourashava has been considerably increased since the last few years. Though high-rise buildings helped in solving the problem of shortage of land and housing, it also caused many problems in different environmental, structural, spatial, functional, socioeconomical, and demographic aspects of the city. Our study was to identify the location of high-rise buildings, to classify these buildings by their uses and to investigate the Structural and functional characteristics of high-rise buildings in Tangail Pourashava. For the study both primary and secondary data were collected, primary data has been collected from field survey and secondary data has been collected from different journals and published and unpublished publications. The study also focused on the existing high-rise buildings safety and security system available in those buildings and made recommendation that the buildings should follow the Bangladesh National Building Code (BNBC) guidance strictly to ensure all safety aspects.
\end{abstract}

Key words: Functional status, High-rise building, Location, Structural status and Tangail pourashava

\section{Introduction}

Bangladesh is one of the highly populated countries in the world where urban population has been rising over time due to the migration from rural sector to industrial or service sector in searching for employment opportunities and leading a qualified living status (Zaman et al., 2010). In Bangladesh, urbanization takes the pattern of rapid increase of urban population, largely because of natural growth and rural-urban migration (Rahman, 2005; Khan, 1982). The country is going to witness a rapid spread of urbanization over the next decade. According to an estimate, more than $50 \%$ of the Bangladesh population will become urbanized by the year 2030 (BURT, 2005). Likely urbanization in Tangail pourashava has resulted in higher population density of 3650 per $\mathrm{km}^{2}$ (Sarker et al., 2006). The main causes of the rapid urbanization in Tangail pourashava are education, whole sale and retail business, government institutions and training center, growth of light industries etc. As Tangail is the central part of Bangladesh, so many people from many regions come to this city for better living, better livelihood and better education. With increasing population in this area, their accommodation has become a challenge to the city. To accommodate the increasing population the numbers of high-rise buildings are also increasing.

"Generally, a high-rise building is considered to be one that extends higher than the maximum reach of available building safety and security equipment (e.g. fire fighting). In absolute numbers, this has been set variously between 75 feet and 100 feet (Knoke, 2006). High-rise buildings can alsobe defined as 'buildings greater than 75 feet' where the building height is measured from the lowest level of fire department vehicle access to the floor of the highest occupiable story (NFPA, 2012; Ronchi and Nilsson, 2013). The main building uses that can be identified to categorize this type of buildings are office buildings, residential buildings (e.g., hotels, apartment buildings) and health care facilities (Hall, 2011).
According to Craighead (2009), the use of a building has considerable influence on its security and fire safety needs. There are different types of high-rise buildings classified according to their primary use and they are mainly office buildings, hotel buildings, residential buildings and mixed used buildings.

Several questions have been prompted about the adequacy of our current safety regulations and emergency procedures for high-rise buildings. Although building codes establish the minimum requirements for the design of a high rise building, additional life safety features are often necessary to mitigate the issues deriving from the complexity of this type of buildings and the additional difficulties in fire fighting and rescue operations (Chien and Wen, 2011). Different factors have been investigated, such as the design of the stairs in general, e.g., number of the stairs, stair width, staircase length, location in the building, etc. (Pauls, 2002; Pauls et al., 2007) or their specific features, e.g., the slope of the stairs (Graat, Midden and Bockholts, 1999), the values for capacity on stairs (Pauls and Jones, 1980; Pauls, 1988), etc. Recent studies have investigated the importance of an appropriate egress strategy when using evacuation elevators. Actual evacuation scenarios showed that, elevators can be used to assist the evacuation of a high-rise building (Averill, et al., 2005; Sekizawa, et al., 1999). Special requirements are also related to emergency power supply and water protection (Bukowski, 2005; Bukowski, 2010b). Evacuation elevators should be also designed to take into account earthquake protection, provision of emergency communication systems and resistance to the spread of contaminants (Klote et al., 1993).

According to BNBC, 2006 part-3 (Chapter 1 and 2), there is a clear guideline for general building requirements in the section 1.4 to 1.29 and 2.1 to 2.17 for Bangladesh which includes occupancy and construction classification, requirements of plots, Plot size, means of access, open space within a plot, general 
height and area limitations, off street parking spaces, street encroachment, community open space and amenities, minimum standard of a dwelling, requirements of parts of building, landscaping, dam proofing and water proofing of floors and walls, existing buildings, buildings and places of architectural value, ventilation, lighting and sanitation, air conditioning and heating, provision of lift and escalators, sound insulation, thermal insulation, lighting protection of buildings, rat proofing and termite proofing of buildings, requirements for building in flood prone and coastal regions, requirements for buildings in other disaster prone areas, special provision for storage of dangerous goods and their classification, occupancy classification, change of use, mixed occupancy, general requirements of all occupancies, residential buildings, educational buildings, institutional buildings, healthcare facilities, business, mercantile buildings, industrial buildings, storage buildings, assembly buildings, hazardous building, garage buildings, utility buildings and, miscellaneous buildings. There is also some guidelines about buildings safety and security in part 4 , chapter 1 and 2 for fire protection, which includes general requirements, fire drill, fire tests and fire resistance rating, occupancy classification, classification of construction types, fire

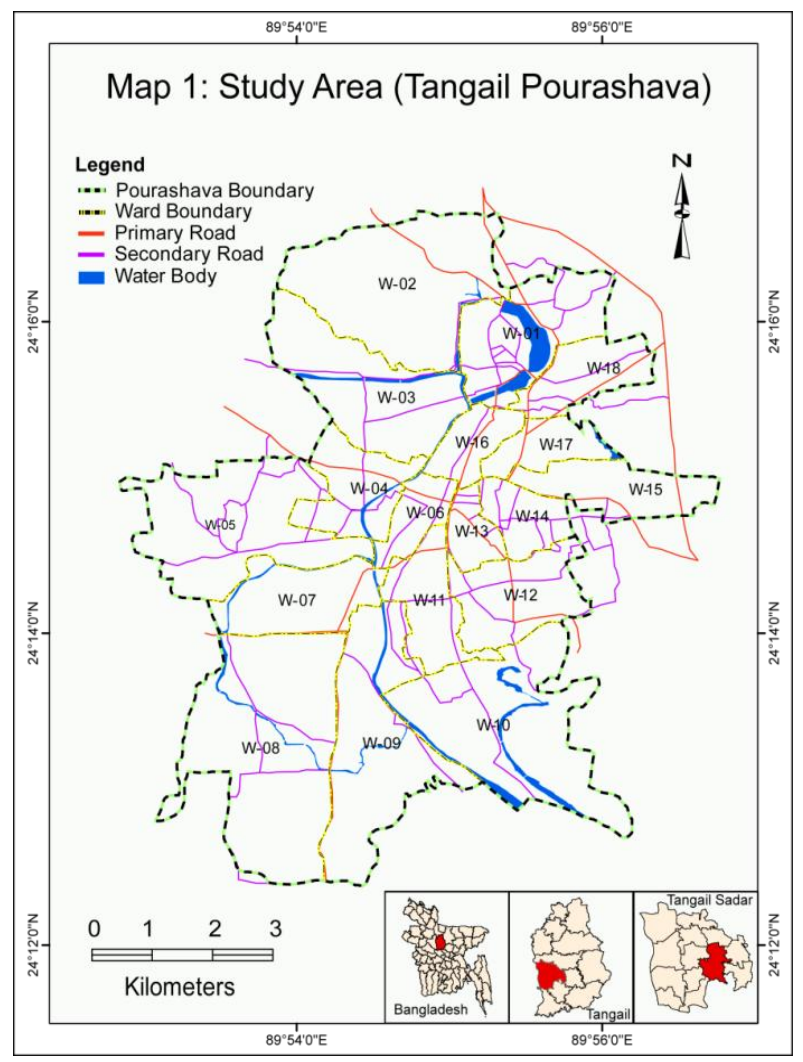

zones, mixed or separated or detached occupancy, openings in separation wall, smoke and heat vents, electrical and gas services, surface finishes, glazing assemblies, skylights, fire lights, utilities and exempted quantities of hazardous material and related index. The guidelines should be followed and the government should establish a strong monitoring system to ensure the implementation of the guidelines effectively.

\section{Objectives of the study}

The aim of the study is to generate knowledge and ideas about the possible building hazard, safety and security system, risk management and recommend preventive measures to fight this phenomenon in Tangail pourashava. The present study is looking at the following specific objectives in order to achieve the broader goals mentioned above. The specific objectives of the study are-

- To identify the location and floor-wise distribution of high-rise buildings in Tangail pourashava

- To know the growth trend of high-rise building in Tangail pourashava and

- To investigate the Structural and functional status of high-rise building in Tangail pourashava

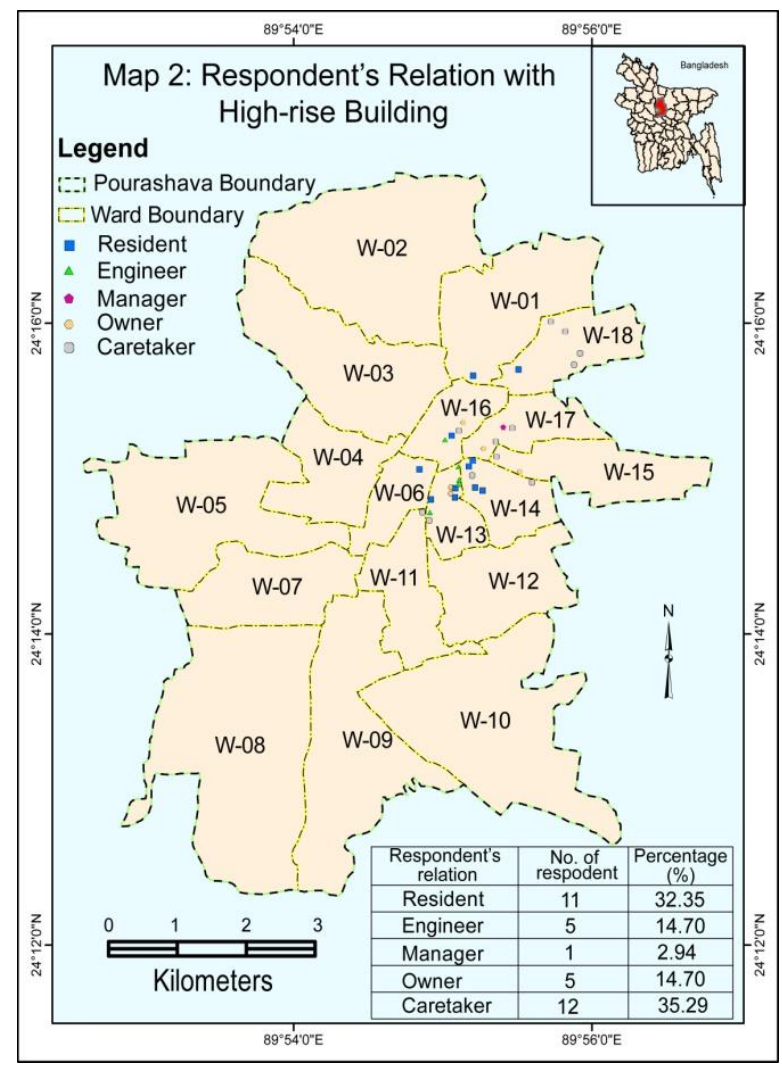




\section{Materials and Methods}

The study area is Tangail pourashava at Tangail district in the central part of Bangladesh. The latitude and the longitude of Tangail district are $24.00^{\circ} \mathrm{N}$ and longitude $90.34^{\circ} \mathrm{E}$ respectively. It lays $98 \mathrm{~km}$ north-west of Dhaka, the capital (Map 1). It is one of the important cities of central region of Bangladesh and main urban area of Tangail district. The city is on the bank of Louhajang river. Tangail municipality was established in1887 and it got shape as a separate district on 1st December, 1969. Tangail sadar thana was formed in 1962 and it was turned into an upazila in 1984. The Tangail paurashava was established in 1987 when there were 5 wards. Latter on new 4 wards were added to the master plan. The total area of Tangail city is $35.22 \mathrm{~km}^{2}$. The pourashava now consists of 18 wards and 64 mahallas till 2016. It has a total population of $1,67,412$ (BBS, 2011). For the study both primary and secondary data were taken. The study method also includes a series of related activities. The first step of the study was to locate the high-rise buildings in Tangail pourashava. The identification of high rise buildings were made in order to find out the number of high-rise buildings ( 7 and above) in each ward. Recent satellite images and existing studies had also been used for the study. Then, a questionnaire survey was carried out in 34 out of 38 high-rise buildings located in Tangail pourashava focusing on the existing high-rise building safety and security system in those buildings. Respondents of the questionnaire survey were owner, manager, caretaker and user of the buildings. Secondary sources of data had been collected from available sources (e.g. journals, published and unpublished report) to gather information on Structural and functional condition in high-rise buildings. The data from the questionnaire survey had been processed and analyzed by using SPSS 11.1 software and MS Excel 2010 program. After data entry had been completed, simple one way tables and graphs had been prepared for the analysis to make the report understandable. The map had been prepared by using Arc GIS 10.3 software. The study was conducted during October and November, 2016.

\section{Results and Discussion}

\section{Location analysis of high-rise buildings}

Location of high-rise buildings in an urban area follows certain status in the context of urban land use. Generally commercial and residential land use contains most of the high-rise buildings in urban areas. In a small city like Tangail, this revolves around single Central Business District (CBD) unlike megacity Dhaka. During the last 8 years, there has been a boost in the construction of high-rise buildings in Tangail pourashava. Nowadays, high-rise buildings are being constructed nearly Central Business District of the Pourashava.

\section{Floor-wise distribution of high rise building}

Recently there is a constructing trend of high-rise buildings in Tangail pourashava. Table 1 shows that the distribution of high rise buildings in Tangail pourashava according to floor numbers. It has been found that the 10 storied buildings were the dominant one accounting for $50 \%$ of the total buildings followed by 7 storied $(18.42 \%)$ and 8 storied $(15.78 \%)$ buildings. It is interesting to note that Tangail pourashava has an increasing number of tall buildings over time and the study found that, the city is growing vertically.

Table 1. Floor-wise distribution of high -rise buildings in Tangail pourashava

\begin{tabular}{|llllllll|}
\hline Ward no. & $\mathbf{7}$ storied & $\mathbf{8}$ storied & $\mathbf{9}$ storied & $\mathbf{1 0}$ storied & $\mathbf{1 1}$ storied & $\mathbf{1 3}$ storied & Total \\
1 & - & - & - & - & 1 & - & $\mathbf{1}$ \\
3 & - & - & 1 & - & - & - & $\mathbf{1}$ \\
6 & 1 & - & - & - & - & - & $\mathbf{1}$ \\
11 & 1 & - & - & - & - & - & $\mathbf{1}$ \\
13 & 2 & 3 & - & 7 & - & 1 & $\mathbf{1 3}$ \\
14 & 1 & 1 & - & 4 & - & - & $\mathbf{6}$ \\
15 & - & - & - & 2 & - & - & $\mathbf{2}$ \\
16 & - & - & 1 & 3 & - & - & 4 \\
17 & 1 & 2 & - & 1 & - & - & 4 \\
18 & 1 & - & - & 2 & 2 & - & $\mathbf{5}$ \\
Total & $\mathbf{7}$ & $\mathbf{6}$ & $\mathbf{2}$ & $\mathbf{1 9}$ & $\mathbf{3}$ & $\mathbf{1}$ & $\mathbf{3 8}$ \\
Percentage & $\mathbf{1 8 . 4 2}$ & $\mathbf{1 5 . 7 8}$ & $\mathbf{5 . 2 6}$ & $\mathbf{5 0}$ & $\mathbf{7 . 8 9}$ & $\mathbf{2 . 6 3}$ & $\mathbf{1 0 0}$ \\
\hline
\end{tabular}

Source: Field survey. November, 2016 (-absent) 


\section{Growth trend of high-rise building}

The number of high-rise buildings in Tangail Pourashava is increasing day by day. Figure 1 shows that the maximum 9 buildings, $23.68 \%$ of high-rise buildings were constructed in 2015 , whereas only one such building was constructed in 2010 .

Fig.1: Growth trend of High-rise Buildings in Tangail Pourashava

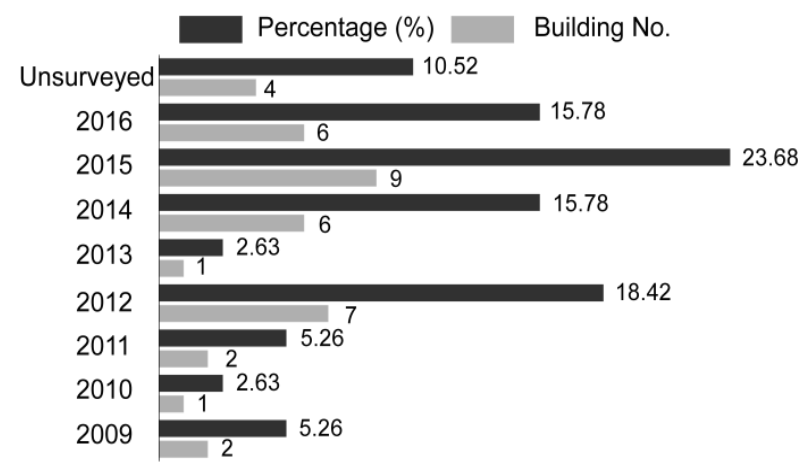

Structural and functional status of high-Rise buildings High-rise building's safety and security largely depends on the Structural and functional status of the building and the socio-economic and cultural settings of their users. The present Structural and functional characteristics of the high rise buildings in Tangail Pourashava are-

Earlier in this study it has been mentioned that a total of 38 high rise buildings were identified. Among them, 34 were surveyed. It would have been more adequate to collect information about the structural and functional status of high-rise buildings from their owners. But, most of these buildings are being taken care of by appointed managers or caretakers or engineer. In this study out of 34 respondents, $5(14.70 \%)$ were the owners, one $(2.94 \%)$ was manager, $11(32.35 \%)$ were residents, $5(14.70 \%)$ were engineers and the remaining $12(35.29 \%)$ respondents were the caretakers (Map 2). Among the surveyed buildings, it has been found that all of the buildings were owned by the private entrepreneurs and of course such investment must be of profit based. Due to an attitude of higher profit by the investors, in many cases the Structural and functional status of buildings as per safety and security standard.

A high-rise building can be used in a number of purposes, by floor or by space. In this study all types of
The study clearly shows that the growth trend of high rise building is very recent as the first construction of such building took place in 2009 and in just 7 years the tally expanded to 38 .

Fig. 2: Use of High-rise Buildings by Story in Tangail Pourashava

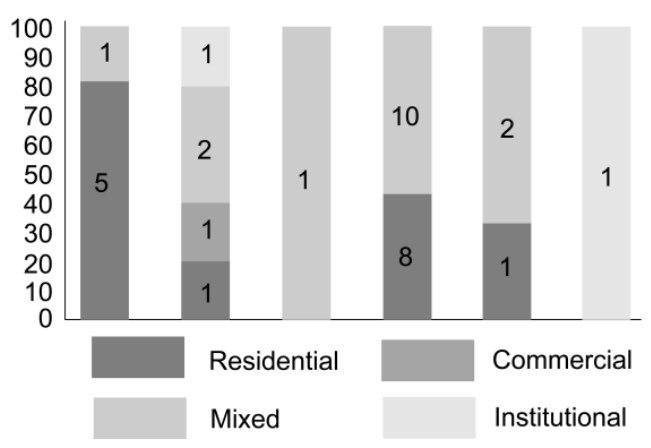

uses have been classified into five major classes. Among those typesit has been found that maximum High-rise buildings are being used for residential purposes (47.05\%). Among the other buildings 2 buildings have been found for commercial and industrial purposes each and the rest are being used for mixed purposes (residential+commercial and residential + institutional) in Tangail pourashava. (Map 3)

The intensity of land use type and density of users of each building at different times of the day is an indicator to understand the use of high-rise buildings by floor. To understand the fire risk and level of loss of lives and properties, it is important to know the use type of the high-rise buildings by floor. The study shows that, among the surveyed buildings, all the seven storied buildings were used for residential purposes except one that was found to be used for mixed purposes. The buildings higher than seven were mostly used for mixed purposes. However, the study shows that there is no definite pattern of uses of high-rise buildings by floor, but bulk majorities of the high-rise buildings are built for residential uses, followed by mixed uses. For example, more than $50 \%$ of 10 storied buildings are being used for mixed purposes, though the most part of the buildings were used for residential purposes (Fig. 2). 


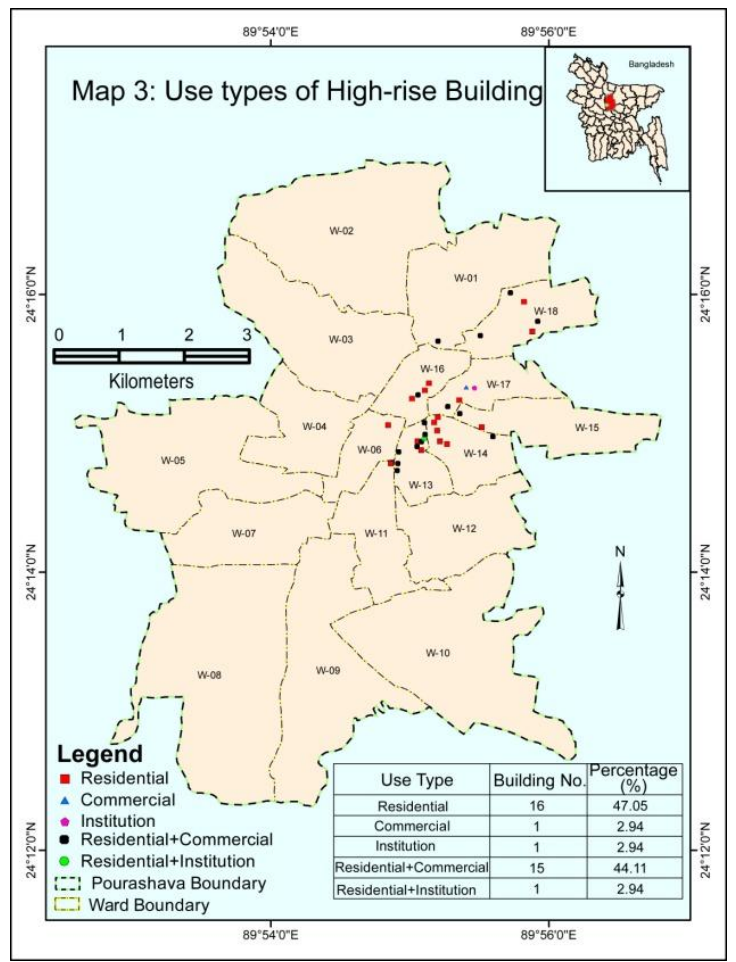

According to Bangladesh National Building Code, high-rise buildings must have the ability to supply electricity using its own sub-station. In this study it has been found that among the 34 surveyed buildings 28 $(82.35 \%)$ buildings do not have any sub-station facility. Among the remaining 6 buildings having electric substations, only $4(11.76 \%)$ buildings have one and 2 $(5.88 \%)$ have only two such sub-stations (Fig. 3).

Fig. 3: Number of Electric Substation in High-rise Buildings in Tangail Pourashava

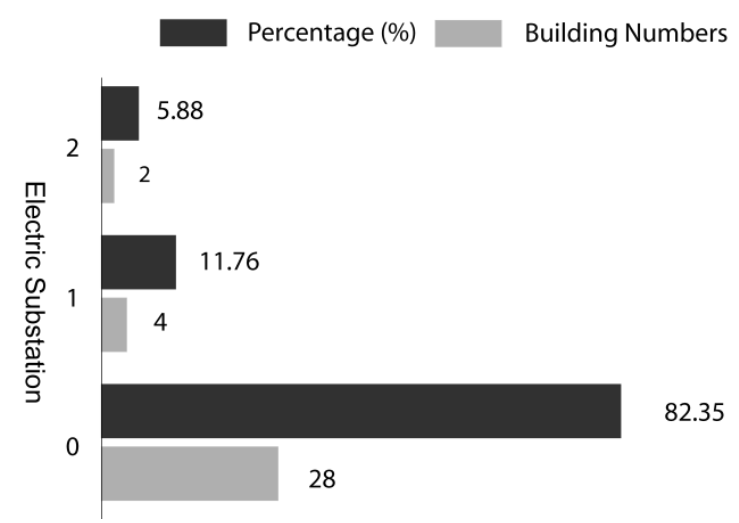

The use of glass as sidewall for high-rise buildings is not environmentally feasible. Nowadays the use of glass sidewalls has become a fashion. In these buildings, glass walls are used in all sides or at least in the main street side. During the day time, because of greenhouse effect, the room temperature of these building becomes much higher than the outside. Moreover, these sidewalls escalate the fire hazard, and make fire fighting and rescue operation more difficult. It has been found that among the 34 surveyed buildings only 4

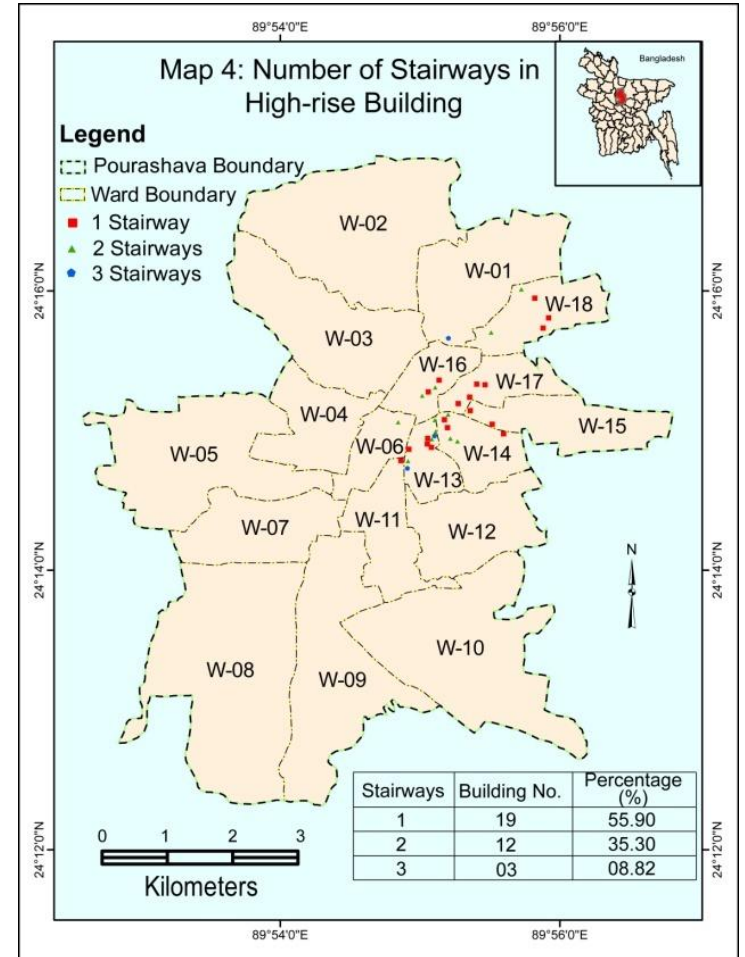

According to Bangladesh National Building Code generators are required for critical safety and security systems such as elevators in high-rise buildings, fire protection systems, standby lighting, or medical and life support equipment. The study shows that only 8 (23.52\%) buildings do not have any generator. And among the remaining 26 buildings, 20 (58.82) buildings have only one generator, $2(5.88 \%)$ buildings have two and $4(11.76 \%)$ buildings have three generators (Fig. 4).

\section{Fig. 4: Generator Facilities in High-rise buildings in Tangail Pourashava}

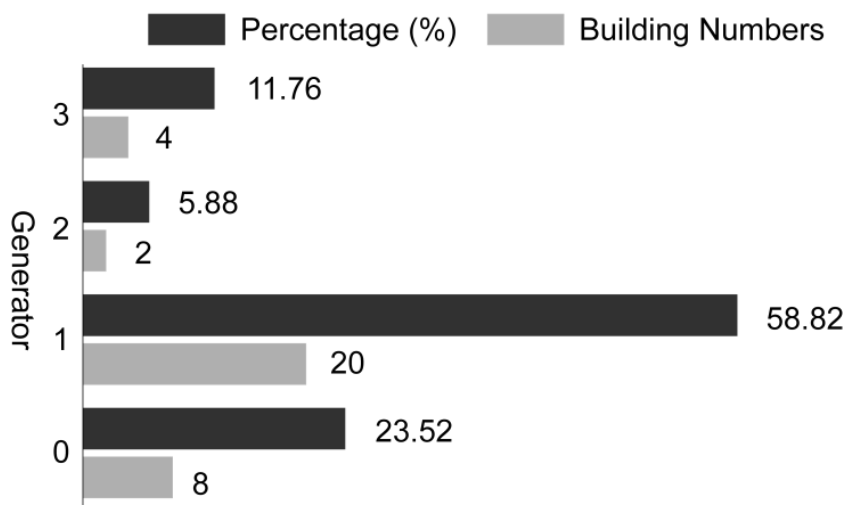

$(11.76 \%)$ buildings have glass sidewall and all of them have glass at 3 sides (Fig. 5). 
According to Bangladesh National Building Code, each high-rise building must have at least one general stair, but the number of stair in such building may vary according to the floor space, number of floors and numbers of people. Among the surveyed buildings, 19 buildings (55.9\%) have only one stair and majority of these buildings are in between seven and eight storied. In this study, 3 buildings $(8.82 \%)$ have been identified with the facility of 3 general stairs. These buildings are mostly in between 10 and 13 storied and are generally used for mixed purposes. The rest of the buildings $(35.3 \%)$ have 2 stairs each (Map 4).

In this study it is observed that, the number of lifts of the buildings used for general purposes. It is found that 6 buildings $(17.64 \%)$ do not have any lift service. The remaining 28 buildings $(82.36 \%)$ have at least one lift, and among them 10 buildings $(29.41 \%)$ have two lifts and 3 buildings $(8.82 \%)$ have four lifts (Map 5). These buildings generally have huge floor space compared to other buildings (Between 8000 to 12000 sq. ft.) and are commonly used for residential and commercial purposes. The average carrying capacity of each lift is in between 8 to 12 persons per trip. (Map 6)

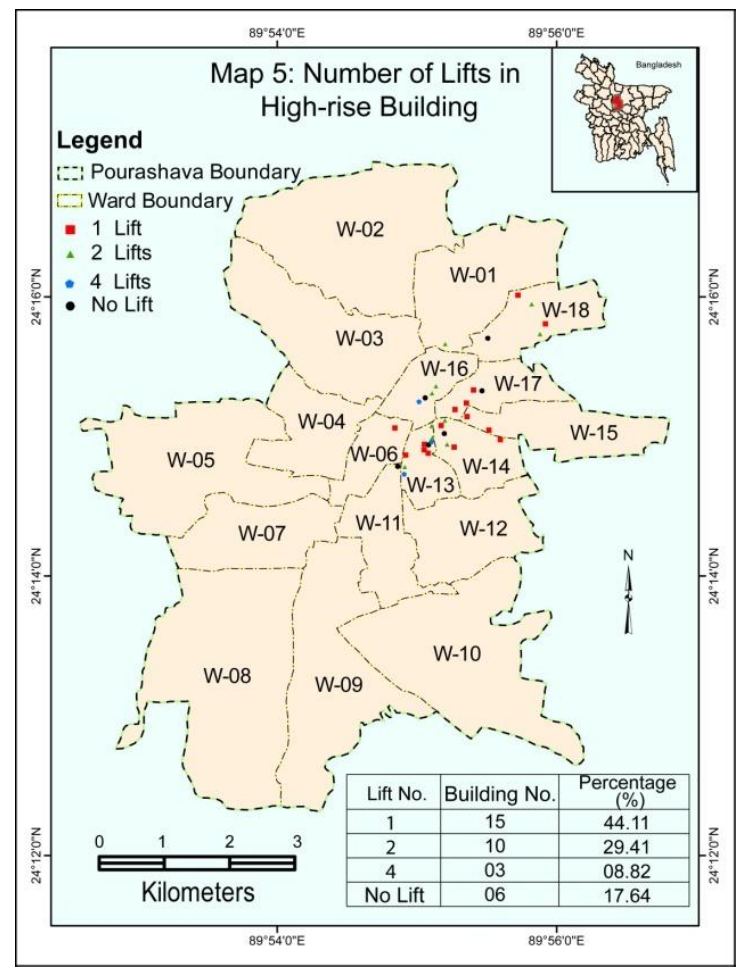

The Bangladesh National Building Code (1993) also includes that emergency stairs must remain open for all the time and the one building we found having emergency exit does remain open all the time but it is
Fig. 5: Number of Buildings having Glass Sidewall

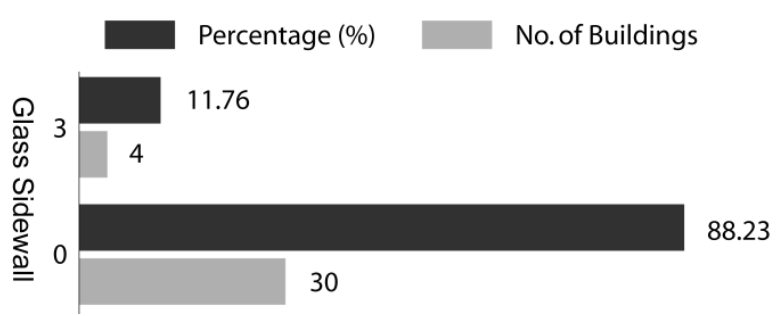

According to Bangladesh National Building Code, 1993 each high-rise building must contain in-house fire protection devices, such as fire alarm, fire extinguisher, hose-pipe etc and for every $1000 \mathrm{sq}$. ft. floor space and of 50 people in each floor, there should be the provision of at least one emergency stair and that must be located at the opposite side of the main stair. Among these, the inclusion of emergency exit is an important measure against fire hazard. The study shows that such rule of the Bangladesh National Building Code has not been followed in most cases. In this study it has been found that only one building has such route. The rest 33 buildings do not have any emergency route to exit at all (Map 7).

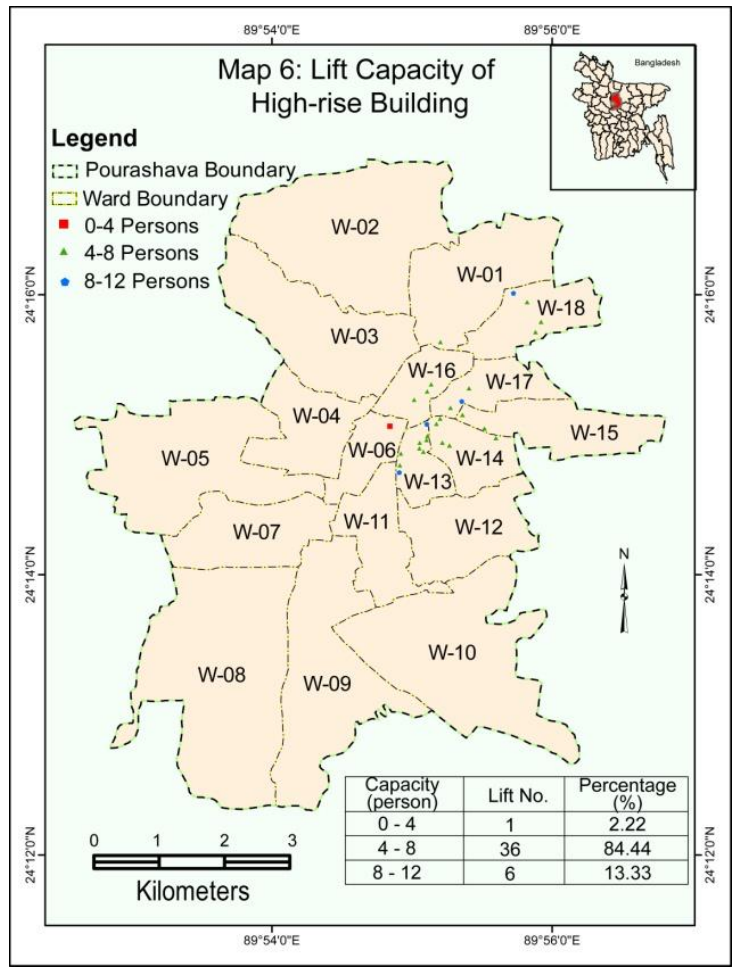

being used for other purposes as well such as regular movement. The number of emergency stair depends on space and uses. 


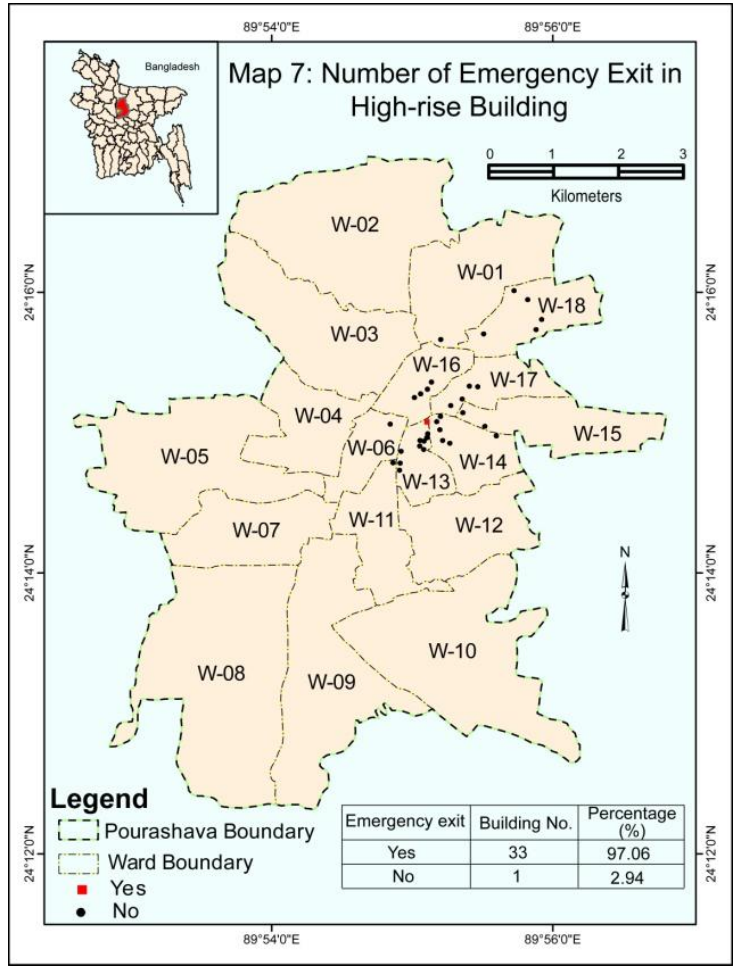

Tangail pourashava is growing vertically due to lack of land and excessive population pressure. To understand the land carrying capacity and population density in high-rise buildings, an important indicator is the floor space of any building in urban area.

In this study it has been found that 9 buildings (26.47\%) have floor space of less than 2500 sq. $\mathrm{ft}$. majority of the buildings (11 buildings) have floor area between 3500 and $4500 \mathrm{sq}$. ft. 5 buildings have been found to have floor space above 6500 sq. ft. with a maximum of 15000 sq. ft. (Map 8).

\section{Conclusion}

The goal of this study was to analyze the Structural and functional status of the high-rise buildings in Tangail pourashava. The study found that in most cases high rise buildings are constructed and fittings are made without considering the incident of hazards. This is due to the violation of Bangladesh National Building Code by the owners of the buildings. This can have effective contributions to failure to uncontrolled expansion of urbanization. However, regardless of its postitive effects, it can have negative and harmful impacts on urban space and the land uses, if not properly considered. To reduce the frequency of hazard and to reduce the casualties it is necessary to strict implementation of Bangladesh National Building Code for Tangail city.

There are some recommendations, which if taken to their fullest extent, can be effective for management of high rise buildings and they are -

- The city should be planned in which the land use should be specified on the basis of zoning plan.

- Majority of the buildings are built without following proper instructions and in this situation,

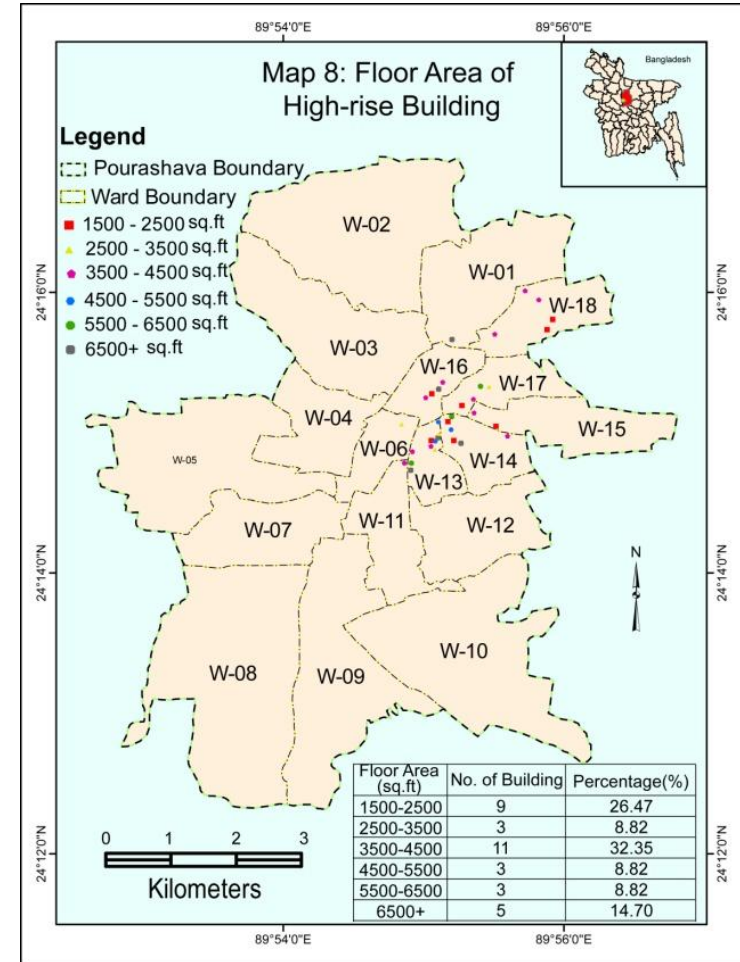

immediate measures should be taken to reinforce fire compliances in each building where necessary.

- Information and drawings of escape routes and information signs should provide in each floors.

- Proper disposal of rubbish and proper use of heat sources like gas cookers. This is extremely dangerous in case of emergency evacuation.

- Every high-rise building should have minimum two staircases, one of them is for accessing basement and another is for general purposes.

- The road which abuts a high rise building to be constructed should be more than 30 feet width to access for fire vehicals.

- The escape route should be marked with a sign board on the corridor \& passage to guide evacuation. Normally, the escape route sign board must be written in luminous paint for easy identification.

- A standby generator should be installed to supply power for staircase lighting, corridor lighting, fire pump, pressurization fan $\&$ blowers, in the event of disconnection of failure of main supply.

- Landing doors of lifts should open to ventilated lobby \& 'fireman switch' should be provided for each lift.

\section{References}

Averill, J. D.; Mileti, D. S.; Peacock, R. D.; Kuligowski, E. D.; Groner, N.; Proulx, G.; Reneke, A. P. and Nelson, H. E. 2005. Final Report on the Collapse of the World Trade Center Towers. Federal Building and Fire Safety Investigation of the World Trade Center Disaster, Occupant Behaviour, Egress and Emergency Communications, September. NIST NCSTAR 17. 
BNBC. 2006. Bangladesh National Building Code. Housing and Building Research Institute, Mirpur, Dhaka, and Bangladesh Standards and Testing Institution, Tejgaon Dhaka, 1st edition. Retrived from. https://www.scribd.com/doc/130997184/ Bangladesh-national-Building-Code-2006-Part-1

Bukowski, R. W. 2010b.Applications of Elevators for Occupant Egress in Fires. Fire Protection Engineering, 38.

Bukowski, R. W. 2005. Protected Elevators For Egress And Access During Fires In Tall Buildings, Workshop on Building Occupant Movement During Fire Emergencies, pp 14-21.

BURT. 2005. Dialogue with Donors on Urban Poverty Issues. Dhaka: CARE-Bangladesh.

Chien, S. W. and Wen, W. J. 2011. A research of the elevator evacuation performance and strategies for Taipei 101 Financial Center. Journal of Disaster Research, 6(6): 581-590.

Craighead, G. 2009. High-rise security and fire life safety. Butterworth-Heinemann.

Graat, E.; Midden, C. and Bockholts, P. 1999. Complex evacuation; effects of motivation level and slope of stairs on emergency egress time in a sports stadium, Safety Science 31, pp. 127-144.

Hall, J. R. 2011. High-Rise building fires. National Fire Protection Association. Fire Analysis and Research Division.

Khan, A. A. M. 1982. Rural-Urban Migration and Urbanization in Bangladesh. The Geographical Review, 72(4): 379-394.

Knoke, M. E. 2006. Managing Editor, CPP. High-rise structures: life safety and security considerations. In: Protection of Assets Manual. Alexandria, VA: ASIS International;

Klote, J .H.; Deal, S.; Donoghue, E. A.; Levin, B. M. and Groner, N. E. 1993. "Fire Evacuation by Elevators.' Elevator World, 41 (6).

NFPA. 2012. National Fire Protection Association.

Pauls, J. L. and Jones, B. K. 1980. Building Evacuation: Research Methods and Case Studies. In: Canter,
D. (Ed.), Fires and Human Behaviour, Wiley, Chichester.

Pauls, J. L.; Fruin, J. and Zupan, J. 2007. Minimum Stair Width for Evacuation, Overtaking Movement and Counterflow: Technical bases and suggestions for the past, present and future. In: Proceedings of the 3rd Pedestrian and Evacuation Dynamics Conference. Editors: Waldau, Gattermann, Knoflacher and Schreckenberg, Springer-Verlag, Berlin, pp. 57-69.

Pauls, J. L. 1988. Egress Time Criteria Related to Design Rules in Codes and Standards. In: Sime, J.D. (Ed.), Safety in the Built Environment, E \& F.N. Spon, New York.

Pauls, J. L. 2002. Evacuation of Large High-Rise Buildings: Reassessing Procedures and Exit Stairway Requirements in Codes and Standards. Proceedings of Fire Protection Strategies for the 21st Century Building and Fire Codes Symposium, pp. 89-96.

Rahman, M. M. 2005. Regionalization of Urbanization and Spatial Development: Planning Regions in Bangladesh. The Journal of Geo-Environment, 4: 31- 46.

Ronchi, E. P. and Nilsson, D. 2013. Assessment of Total Evacuation Systems for Tall Buildings: Literature Review. Quincy, MA: Fire Protection Research Foundation.

Sarker, B. C.; Shutradhar, S. C.; Khan, A.; Saifullah, A. S. M. and Ruma, A. B. 2016. Urban Growth and its Impact on Tangail Municipal Area. Journal of Environmental Science and Natural Resources, 8(2): 163-166.

Sekizawa, A.; Ebihara, M. E.; Notake, H.; Kubota, K.; Nakano, M.; Ohmiya, Y. and Kaneko, H. 1999. Occupants' Behaviour in Response to the Highrise apartments Fire in Hiroshima City. Fire and Materials. Special Issue: Human Behaviour in Fire 23(6): 297-303.

Zaman, A. K. H. H. U.; Alam, K. M. T. and Islam, M. J. 2010. Urbanization in Bangladesh: present status and policy implications. ASA University Review, 4(2): 1-16. 